\title{
Discipline Analysis Of Work, Motivation And Loyalty Towards Employee Performance (Case Study At Gorontalo State University)
}

\author{
Fandy Nugroho Hardiknasiono Musa ${ }^{1}$, Altje Tumbel ${ }^{2}$, Magdalena Wullur ${ }^{3}$ \\ ${ }^{1}$ Student of Master Management Study Program, Faculty of Economics and \\ Business, Sam Ratulangi University, Manado \\ 23 Faculty of Economics and Business, Sam Ratulangi University, Manado
}

Received: 12 Januari 2021; Revised: 26 Februari 2021; Accepted: 28 April 2021 DOI: http://dx.doi.org/10.37905/aksara.7.2.449-462.2021

\begin{abstract}
This study aims to partially determine the positive and significant influence of work discipline, motivation and loyalty on employee performance at Gorontalo State University. The population in this study is the State Civil Apparatus at Gorontalo State University, amounting to 247 people. The data collection method uses a questionnaire that is by collecting data through a list of questions and distributing questionnaires to employees at Gorontalo State University. The research results obtained that there is a significant influence by work discipline on employee performance in the Gorontalo State University environment. The better the application of work discipline on employees will also improve employee performance. There is a significant influence by work motivation on employee performance in the State University of Gorontalo. The high level of motivation possessed by employees is one of the keys in improving employee performance. So the existence of programs that are motivating work must be intensified even more. There is a significant influence by loyalty on the performance of employees in the environment of Gorontalo State University. Employee loyalty is the reason why labor turn over is so low. This was also triggered by the university's commitment to opening opportunities for its employees including honorary employees in achieving good career paths. There is a significant influence by work discipline, motivation, and loyalty simultaneously on employee performance in Gorontalo State University. This indicates that work discipline alone is not enough to stimulate employee performance. The implementation of preventive policies to direct employee behavior to be disciplined must also be supported by the existence of programs that can motivate employee work. That way employee loyalty can also be created and enhanced. Synergy between the three variables will have a positive impact on improving employee performance so that it will also affect the overall university performance as an outcome of employee performance. All of these factors are needed considering the vision of the university as a leading university in the Southeast Asian region which certainly requires strong support and commitment as well as good performance from all elements in Gorontalo State University.
\end{abstract}

Keywords: Work Discipline, Motivation, Loyalty and Employee Performance

\section{Pendahuluan}

Kinerja pegawai dalam suatu organisasi tidak bisa dilepaskan dari adanya motivasi yaitu keadaan pribadi seseorang yang memberikan dorongan kepada individu untuk melakukan kegiatan-kegiatan tertentu demi mencapai suatu tujuan 
(Sarworini, 2007:3). Motivasi pegawai bisa dilakukan dengan penyesuaian antara tujuan individu dengan sasaran organisasi. Atasan harus memaksimalkan motivasi jika ingin memperoleh kinerja yang optimal dari pegawainya. Memaksimalkan motivasi pegawai dalam mencapai tujuan organisasi adalah tujuan pokok penilaian kinerja (Slamet, 2007:238).

Menurut Slamet (2007:232) melalui penilaian kinerja dapat diperoleh informasi yang akurat dan sahih tentang kemampuan anggota-anggota organisasi melaksanakan pekerjaannya. Hasil penilaian kinerja dapat digunakan sebagai dasar evaluasi kinerja anggota organisasi. Berdasarkan pada informasi dari sistem penilaian kinerja inilah seorang pegawai dapat dinilai apakah kompeten atau tidak kompeten, efektif atau tidak efektif, dapat dipromosikan atau tidak dipromosikan. Karena itulah agar kinerja pegawai meningkat maka pegawai tersebut perlu dimotivasi (Simamora, 2015:424). Motivasi sangat penting karena motivasi merupakan suatu hal yang menyebabkan, menyalurkan dan mendukung perilaku manusia, agar lebih antusias dan giat bekerja demi mencapai hasil yang optimal (Hasibuan, 2017:141). "Motivasi dikatakan sebagai kebutuhan yang mendorong perbuatan ke arah suatu tujuan tertentu" (Anoraga, 2014:34). Motivasi penting dalam meningkatkan kinerja pegawai sehingga agar tujuan organisasi tercapai maka organisasi harus dapat menggerakkan dan mendorong pegawainya agar lebih semangat bekerja. membentuk etos kerja yang produktif (Sinungan, 2014:146). Menurut Peraturan Pemerintah Nomor 53 Tahun 2010 telah diatur secara jelas bahwa kewajiban yang harus ditaati dan larangan yang tidak boleh dilanggar oleh setiap Aparatur Sipil Negara dan merupakan bentuk disiplin yang ditanamkan kepada setiap Aparatur Sipil Negara. Kedisiplinan pegawai sangat penting guna mematuhi peraturan, prosedur, maupun kebijakan yang ada, sehingga dapat menghasilkan kinerja yang baik (Slamet, 2007:214-215). Disiplin sangat penting memacu pegawai agar dapat mendisiplinkan diri dalam melaksanakan pekerjaan baik secara individu maupun kelompok demi pertumbuhan organisasi (Slamet, 2007:214). Pegawai yang mendisiplinkan diri berarti pegawai tersebut menghargai diri dan rekan kerjanya karena pegawai tersebut sudah mematuhi peraturan yang ada dan menghasilkan kinerja yang baik dengan bekerja sama dengan rekan kerjanya.

Disiplin sangat penting karena semakin disiplin pegawai maka semakin tinggi pula kinerja pegawai (Hasibuan, 2017:193). Menurut Anoraga (2014:47) kesadaran akan berdisiplin sangat diperlukan untuk meningkatkan keahliannya sehingga tercapai prestasi kerja yang optimal. Meningkatnya keahlian yang diikuti dengan disiplin tinggi, masuk dan pulang kerja tepat pada waktunya, taat pada peraturan maka tugasnya akan efisien. "Absennya pegawai dapat menjadi dasar pengukuran motivasi, semakin banyak pegawai yang absen berarti tingkat motivasi mereka untuk menyelesaikan pekerjaannya semakin rendah dan berimbas pada kinerja pegawai" (Sarworini, 2007:4). Selain itu menurut Sinungan (2014:148) mangkir dari pekerjaan merupakan salah satu gejala erosi disiplin yang akan menghambat pembangunan. Aparatur adalah salah satu elemen yang memegang tanggung jawab dalam suatu organisasi, baik itu dalam perencana, pelaksana dan penggerak serta sekaligus bertindak sebagai pengawas dalam pembangunan bangsa ini. 
Menurut Zainun (2014), motivasi kerja seorang karyawan akan berpengaruh terhadap kinerja yang dapat dicapai murni hanya timbul dari dalam diri seorang karyawan (motivasi internal) atau motivasi berasal dari luar karyawan yang bersangkutan (motivasi eksternal). Menurut Zainun (2014), motivasi dapat dipandang sebagai bagian integral dari administrasi kepegawaian dalam rangka proses pembinaan, pengembangan dan pengarahan tenaga kerja dalam suatu organisasi. Motivasi sebagai suatu usaha positif dalam menggerakkan, mengerahkan dan mengarahkan daya dan potensi tenaga kerja agar secara produktif berhasil mencapai dan mewujudkan tujuan yang telah ditetapkan sebelumnya dan sebagai perangsang untuk menggerakkan, mengerahkan dan mengarahkan potensi serta daya kerja manusia tersebut kearah yang diinginkan.

Menurut Hasibuan (2017), motivasi adalah pemberian daya penggerak yang menciptakan kegairahan kerja seseorang, agar mereka mau bekerjasama, bekerja efektif dan terintegrasi dengan segala dan upayanya untuk mencapai kepuasan. David Mc.Clelland dengan teori motivasi prestasi dalam Edy Sutrisno (2016:128) menjelaskan motivasi adalah kondisi yang mendorong seseorang untuk mencapai prestasi secara maksimal.

Kebutuhan Prestasi Menurut Kamus Besar Bahasa Indonesia, prestasi adalah hasil yang telah dicapai. Prestasi dapat dicapai dengan menggunakan kemampuan intelektual, spiritual, dan emosional, serta ketahanan diri terhadapsegala situasi dalam aspek kehidupan. Kebutuhan Prestasi akan mendorong seseorang berprestasi dalam keadaan bila target yang akan dicapai nyata dan memiliki peluang untuk diperoleh serta cenderung menimbulkan kreatifitas pada seseorang. Kebutuhan Prestasi dirumuskan dan menetapkan bahwa pencapaian perilaku yang terkait adalah hasil dari konflik antara harapan sukses dan takut gagal. Kecenderungan pendekatan dan penghindaran terdiri dari fungsi kebutuhan pencapaian, harapan dari keberhasilan dan kegagalan, dan nilai insentif dari keberhasilan dan kegagalan.

Kebutuhan Kekuasaan Kekuasaan adalah kemampuan individu atau kelompok untuk mempengaruhi tingkah laku orang atau kelompok lain sesuai dengan keinginan individu tersebut. Seseorang yang memiliki tingkat Kebutuhan Kekuasaan yang tinggi cenderung berperilaku lebih tegas. Veroff dalam Nindyati (2014) mendefinisikan tujuan kebutuhan kekuasaan sebagai mengerahkan pengaruh dan mencari peningkatan subkategori yang sudah ditetapkan sebagai bagian dari tujuan perilaku untuk memperoleh kebutuhan prestasi. Hasibuan (2017), mengemukakan bahwa loyalitas atau kesetiaan merupakan salah satu unsur yang digunakan dalam penilaian karyawan yang mencakup kesetiaan terhadap pekerjaannya, jabatannya dan organisasi. Kesetiaan ini dicerminkan oleh kesediaan karyawan menjaga dan membela organisasi didalam maupun diluar pekerjaan dari rongrongan orang yang tidak bertanggung jawab. Poerwopoespito (2004), menyebutkan bahwa loyalitas kepada pekerjaan tercermin pada sikap karyawan yang mencurahkan kemampuan dan keahlian yang dimiliki, melaksanakan tugas dengan tanggungjawab, disiplin serta jujur dalam bekerja. Poerwopoespito (2004), juga menjelaskan bahwa sikap karyawan sebagai bagian dari perusahaan yang paling utama adalah loyal. Lebih jauh lagi dijelaskan oleh Nitisemito (2002) bahwa loyalitas merupakan suatu sikap mental karyawan yang ditunjukkan kepada keberadaan perusahaan sehingga karyawan akan tetap bertahan dalam perusahaan, 
meskipun perusahaan tersebut maju atau mundur. Sikap mempunyai sisi mental yang mempengaruhi individu dalam memberikan reaksi terhadap stimulus mengenai dirinya yang diperoleh dari pengalaman dan masing-masing individu dapat merespon stimulus tidaklah sama. Terdapat respon secara positif dan ada yang merespon secara negatif.

\section{METODE PENELITIAN}

Penelitian ini merupakan penelitian survei dengan menggunakan pendekatan kuantitatif. Pendekatan kuantitatif merupakan pendekatan penelitian dengan menekankan pada pengujian teori-teori melalui pengukuran variabel- variabel secara angka dan melakukan analisis data dengan menggunakan prosedur statistik, serta bertujuan untuk menguji hipotesis (Indriantoro dan Supomo, 2002).

Lokasi penelitian di Universitas Negeri Gorontalo. Objek penelitian yaitu Aparatur Sipil Negara (Non Dosen) di Universitas Negeri Gorontalo.

Populasi adalah keseluruhan jumlah objek atau subjek yang memiliki karakteristik dan kualitas yang ditentukan oleh peneliti sehingga didapatkan kesimpulan (Sujarweni, 2014). Populasi dalam penelitian ini adalah Aparatur Sipil Negara di Universitas Negeri Gorontalo yang berjumlah 247 orang.

Menurut Sugiyono (2017:81) Sampel adalah bagian dari jumlah dan karakteristik yang dimiliki oleh populasi tersebut. Bila populasi besar dan peneliti tidak mungkin mempelajari semua yang ada pada populasi, misalnya karena keterbatasan dana, tenaga dan waktu, maka peneliti dapat menggunakan sampel yang diambil dari populasi itu. Sampel yang akan digunakan dalam penelitian ini diambil dari Aparatur Sipil Negara (Non Dosen) yang berumur $\leq 40$ Tahun yang berjumlah 71 orang. Terdapat dua jenis sumber data dalam penelitian yaitu sumber data primer dan sumber data skunder

\section{HASIL DAN PEMBAHASAN}

Penelitian ini dilaksanakan dengan menggunakan pendekatan kuantitatif di mana peneliti bertujuan untuk menganalisis hubungan antara disiplin kerja, motivasi, loyalitas, dan kinerja pegawai di lingkungan Universitas Negeri Gorontalo. Data yang dikumpulkan oleh peneliti di analisis dengan menggunakan teknik analisis regresi linier berganda. Sebagaimana analisis yang terdapat pada statistik parametrik pada umumnya data yang digunakan dalam penelitian terlebih dahulu harus memenuhi asumsi sebagai syarat dilaksanakannya analasis regresi. Uji asumsi yang dilakukan peneliti meliputi uji normalitas, uji multikolinearitas, dan uji heteroskedastisitas.

Pada pengujian normalitas data, acuan dalam menentukan apakah data berdistribusi normal atau tidak adalah dengan melihat nilai signifikansi pada tabel kolmogrov smirnov. Apabila lebih besar dari 0.05 maka berarti data berdistribusi normal, sebaliknya jika nilai signifikansinya lebih kecil dari 0.05 maka data dikatakan tidak berdistribusi normal. Selain itu, normalitas data juga diuji dengan menggunakan diagram p-plot dengan ketentuan apabila pola titik-titik menyebar searah dan berada tidak jauh atau disekitar garis diagonal maka data dikatakan normal. Hasil pengujian normalitas dapat dilihat pada sajian tabel dan gambar berikut: 
Tabel One-Sample Kolmogorov-Smirnov Test

\begin{tabular}{|ll|r|r|r|r|}
\hline & & $\begin{array}{l}\text { Disiplin } \\
\text { Kerja }\end{array}$ & $\begin{array}{l}\text { Motivas } \\
\text { i }\end{array}$ & $\begin{array}{l}\text { Loyalita } \\
\text { s }\end{array}$ & \multicolumn{2}{l}{ Kinerj } \\
a
\end{tabular}

a. Test distribution is Normal.

b. Calculated from data.

Sumber: Data Kuisioner Diolah (2019)

Dapat dilihat pada tabel di atas bahwa nilai signifikansi dari masing- masing variabel adalah 0,113 untuk disiplin kerja (X1), 0,078 untuk motivasi (X2), 0,128 untuk loyalitas (X3), dan 0,152 untuk kinerja (Y). setiap nilai signifikansi yang diperoleh berada pada level di atas dari 0,05 . Sebagaimana kriteria yang telah ditentukan, maka data penelitian dinyatakan terdistribu normal.

\section{Normal P-P Plot of Regression Standardized Residual}

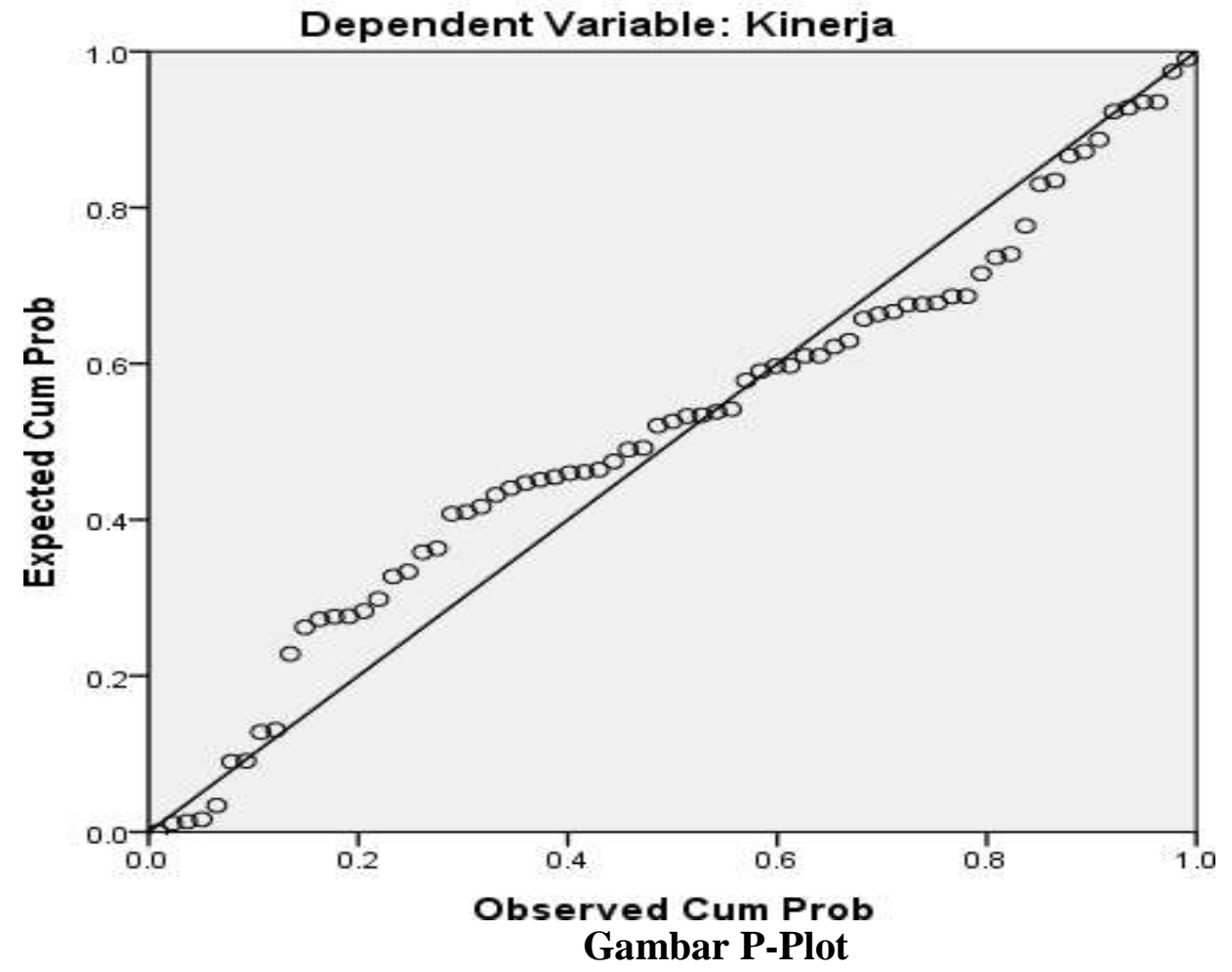

Hasil yang diperoleh dari gambar di atas juga turut memperkuat asumsi 
normalitas pada tabel smirnov, di mana sebaran pola titik berada searah dan masih disekitaran garis diagonal. Sehingga mengacu pada hasil tersebut, maka data yang digunakan dalam penelitian ini dikatakan normal.

Uji multikolinearitas ini dilakukan untuk melihat adanya korelasi antar variabel. Pengujian dilakukan dengan melihat nilai VIF yang diperoleh dari pengujian hipotesis. Apabila nilai VIF lebih besar dari 10.00, maka terjadi multikolinearitas, begitu pula sebaliknya apabila nilai VIF lebih kecil 10.00 maka tidak terjadi multikolinearitas.

\section{Tabel Coefficients ${ }^{\mathrm{a}}$}

\begin{tabular}{|l|r|r|}
\hline \multirow{2}{*}{ Model } & \multicolumn{2}{|c|}{ Collinearity Statistics } \\
\cline { 2 - 3 } & Tolerance & \multicolumn{1}{c|}{ VIF } \\
\hline (Constant) & .847 & 1.180 \\
Disiplin Kerja & .506 & 1.975 \\
Motivasi & .516 & 1.940 \\
Loyalitas & & \\
\hline
\end{tabular}

Sumber: Data Kuisioner Diolah (2019)

Berdasarkan hasil uji multikolinearitas, bisa disimpulkan bahwa tidak terjadi multikolinearitas antar variabel. Kesimpulan diambil dengan melihat nilai VIF dari masing-masing variabel dimana nilai untuk variabel $\mathrm{X} 1=1,180, \mathrm{X} 2=$ $1,975, \mathrm{X} 3=1,940$. Sebagaimana syarat untuk uji multikolinearitas, variabel dinyatakan bebas dari persoalan multikolinearitas dikarenakan nilai VIF $<10$.

Uji heteroskedastisitas dilakukan untuk menguji apakah dalam model terjadi ketidaksamaan varian dari residual untuk semua pengamatan dengan melihat sebaran titik pada grafik scatterplot. Apabila titik menyebar di atas dan di bawah angka 0 sumbu Y maka tidak terjadi heteroskedastisitas. Model dikatakan baik apabila tidak terjadi heteroskedastisitas yang artinya tidak ada gangguan yang berarti dalam model ini. 


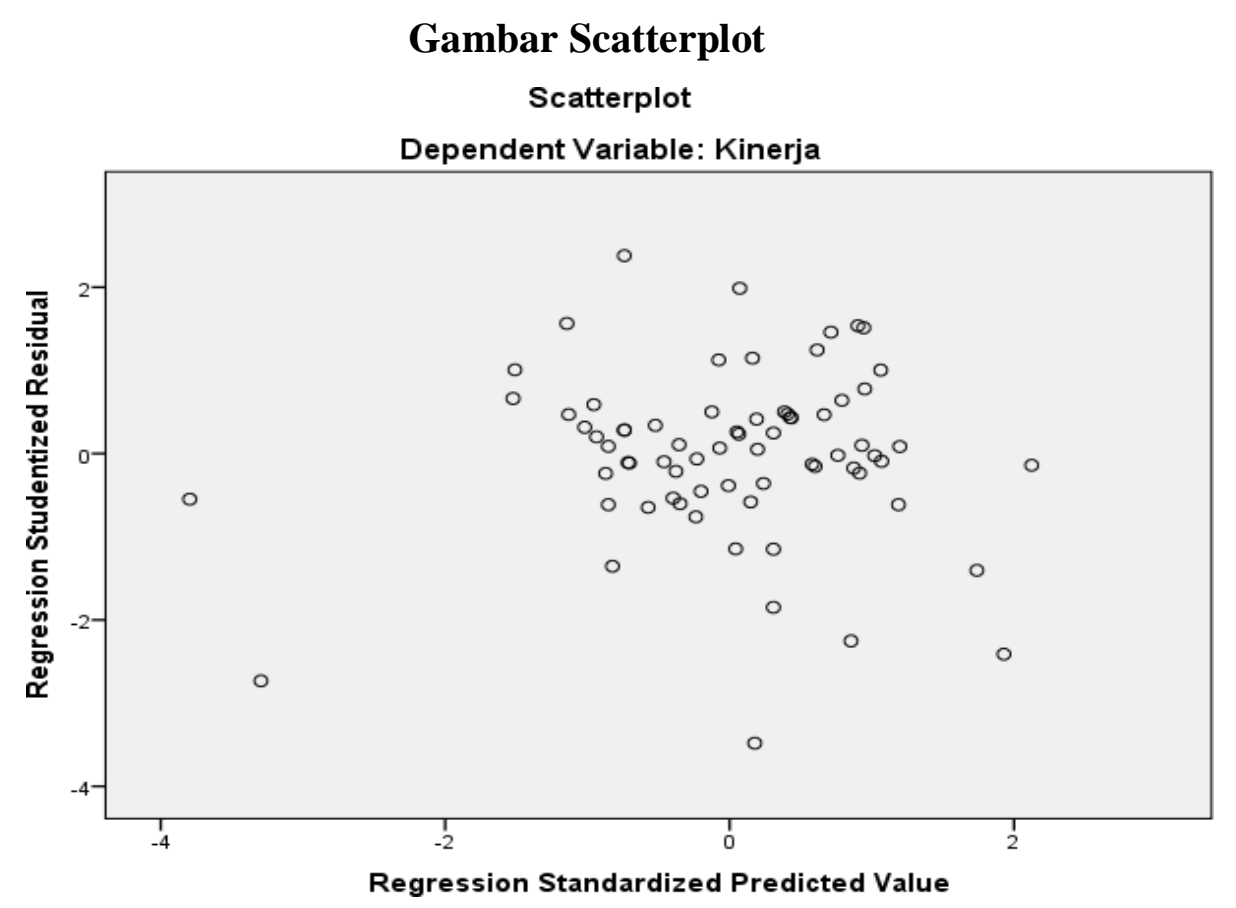

Merujuk hasil pengujian heteroskedastisitas, pola penyebaran dari titik- titik berada di atas dan di bawah 0 sumbu $\mathrm{Y}$ sehingga diambil kesimpulan model ini tidak memiliki gejala heteroskedastisitas atau tidak ada gangguan yang berarti dalam model ini.

Teknik analisis data yang digunakan dalam penelitian ini adalah regresi linier berganda. Analisis ini dipakai untuk mengestimasi besaran pengaruh baik secara parsial oleh variabel $\mathrm{X} 1$ terhadap variabel $\mathrm{Y}$, variabel $\mathrm{X} 2$ terhadap variabel $\mathrm{Y}$, variabel $\mathrm{X} 3$ terhadap variabel $\mathrm{Y}$ serta pengaruh secara simultan oleh

$\mathrm{X} 1, \mathrm{X} 2$, dan X3 terhadap Y. Analisis ini juga dilakukan untuk menjawab dugaan atau hipotesis penelitian untuk melihat apakah ada pengaruh yang terjadi secara parsial maupun simultan.

\section{Pengujian Hipotesis}

Pengujian hipotesis secara parsial dilakukan dengan cara membandingkan nilai thitung yang diperoleh dengan ttabel. Jika nilai thitung lebih besar dari tabel maka $\mathrm{H} 0$ ditolak, dan jika nilai thitung lebih kecil dari nilai ttabel maka $\mathrm{H} 0$ diterima. Taraf signifikansi yang digunakan dalam penelitian ini yakni 0,05 atau 5\%, dengan kata lain peluang terjadinya kesalahan dalam pengambilan keputusan adalah $5 \%$ sedangkan peluang benar adalah $95 \%$. Pada tingakatan ini, maka acuan ttabel yang digunakan adalah 1,666 dengan $(\mathrm{df})=71$. Sedangkan untuk pengujian hipotesis simultan dilakukan dengan cara membandingkan nilai Fhitung yang diperoleh dengan Ftabel, dengan kriteria yang sama dengan perbandingan nilai t. Acuan untuk Ftabel adalah sebesar 2,777. 
Tabel Perolehan Nilai T dan Nilai F

\begin{tabular}{|l|c|c|c|c|c|}
\hline $\begin{array}{l}\text { Pengaruh } \\
\text { Antar } \\
\text { Variabel }\end{array}$ & $\begin{array}{c}\text { Koefisien } \\
\text { Beta }\end{array}$ & $\begin{array}{l}\text { Nilai t- } \\
\text { hitung }\end{array}$ & P-value & $\begin{array}{c}\text { Nilai f- } \\
\text { hitung }\end{array}$ & Keterangan \\
\hline X1terhadap Y & 0,898 & 3,815 & 0,000 & - & Berpengaruh \\
\hline X2 terhadap Y & 1,285 & 6,239 & 0,000 & - & Berpengaruh \\
\hline X3 terhadap Y & 0,871 & 10,850 & 0,000 & - & Berpengaruh \\
\hline $\begin{array}{l}\text { X1, X2, X3 } \\
\text { terhadap Y }\end{array}$ & - & - & 0,000 & 42,480 & Berpengaruh \\
\hline
\end{tabular}

Sumber: Data Kuisioner Diolah (2019)

\section{Pengaruh Disiplin Terhadap Kinerja Pegawai}

Hasil pengujian hipotesis menunjukkan bahwa nilai thitung diperoleh sebesar 3,815. Nilai ini jika dibandingkan dengan nilai tabel yang sebesar 1,666 maka lebih besar nilai thitung. Sehingga dapat disimpulkan bahwa $\mathrm{H} 1$ diterima atau dengan kata lain, terdapat pengaruh disiplin kerja terhadap kinerja pegawai di lingkungan Universitas Negeri Gorontalo. P-Value sebesar 0,000 mengindikasikan bahwa pengaruh yang diberikan sangat signifikan.

2. Pengaruh Motivasi Terhadap Kinerja Pegawai

Hasil pengujian hipotesis menunjukkan bahwa nilai thitung diperoleh sebesar 6,239. Nilai ini jika dibandingkan dengan nilai tabel yang sebesar 1,666 maka lebih besar nilai thitung. Sehingga dapat disimpulkan bahwa $\mathrm{H} 2$ diterima atau dengan kata lain, terdapat pengaruh motivasi kerja terhadap kinerja pegawai di lingkungan Universitas Negeri Gorontalo. P-Value sebesar 0,000 mengindikasikan bahwa pengaruh yang diberikan sangat signifikan.

3. Pengaruh Loyalitas Terhadap Kinerja Pegawai

Hasil pengujian hipotesis menunjukkan bahwa nilai thitung diperoleh sebesar 10,850. Nilai ini jika dibandingkan dengan nilai ttabel yang sebesar 1,666 maka lebih besar nilai thitung. Sehingga dapat disimpulkan bahwa H3 diterima atau dengan kata lain, terdapat pengaruh loyalitas terhadap kinerja pegawai di lingkungan Universitas Negeri Gorontalo. P-Value sebesar 0,000 mengindikasikan bahwa pengaruh yang diberikan sangat signifikan.

4. Pengaruh Disiplin, Motivasi, dan Loyalitas terhadap Kinerja Pegawai

Hasil pengujian hipotesis menunjukkan bahwa nilai Fhitung diperoleh sebesar 42,480. Nilai ini jika dibandingkan dengan nilai Ftabel yang sebesar 2,777 maka lebih besar nilai Fhitung. Dapat disimpulkan bahwa H4 diterima atau dengan kata lain, terdapat pengaruh disiplin kerja, motivasi kerja, dan loyalitas secara simultan terhadap kinerja pegawai di lingkungan Universitas Negeri Gorontalo. P-Value sebesar 0,000 mengindikasikan bahwa pengaruh yang diberikan sangat signifikan.

Sebagai universitas tertua di Provinsi Gorontalo, Universitas Negeri Gorontalo menjadi poros penting dalam memproduksi sumber daya manusia yang 
berkualitas unggul dan berdaya saing. Dalam rangka menjawab tantangan globalisasi, peran Universitas Negeri Gorontalo sebagai lembaga pendidikan sangat penting sebab para lulusan diharapkan dapat terserap dalam pasar kerja yang saat ini tengah bertransformasi ke arah pasar bebas. Untuk itu, demi menciptakan lulusan berkualitas, maka kinerja universitas terus digenjot dari berbagai aspek mulai dari perbaikan struktur kurikulum yang berbasis pasar, hingga upaya meningkatkan reputasi universitas melalui pencapaian akreditasi juga terus diusahakan. Hal tersebut juga dilakukan dalam rangka pencapaian visi universitas sebagai leading university di kawasan Asia Tenggara yang ditargetkan akan tercapai di tahun 2035 nanti.

Dalam upaya untuk mencapai tujuan tersebut, maka diperlukan dukungan dari seluruh elemen baik dosen maupun pegawai, terutama peningkatan kinerja sangat diutamakan. Ini sebagaimana diungkapkan oleh Buhler (2007) bahwasannya kinerja anggota organisasi memiliki korelasi erat dengan kinerja organisasi. Dari pendapat tersebut, dapat disimpulkan bahwa peningkatan kinerja pegawai akan berdampak pada meningkatnya kinerja universitas secara keseluruhan sebagai outcome dari kinerja pegawai itu sendiri. Maka dari itu, guna mencapai tujuan universitas sebagaimana tercantum dalam visi misi universitas, perbaikan kinerja pegawai adalah yang terlebih dahulu harus ditingkatkan.

Meningkatkan kinerja pegawai di lingkungan Universitas Negeri Gorontalo dibutuhkan upaya keras dan dana yang tidak sedikit pula. Hal ini mengingat kinerja pegawai juga berkaitan dengan banyak faktor laten seperti di antaranya motivasi, loyalitas, kedisiplinan, dan lain-lain yang merupakan manifestasi dari

perilaku organisasi dan juga bagian dari manajemen sumber daya manusia. Korelasi antara disiplin, motivasi, dan loyalitas dengan kinerja pegawai pun telah banyak dibahas dalam literatur-literatur manajemen sumber daya manusia. Berikut adalah uraian pembahasan mengenai hubungan antara keempat variabel berdasarkan hasil pengujian statistik yang dilakukan.

\section{Disiplin kerja dan kinerja pegawai}

Salah satu karakteristik yang dimiliki oleh pegawai yang berkualitas adalah adanya perilaku disiplin. Perilaku disiplin kerap kali dikaitkan dengan persoalan presensi serta kesediaan dalam menaati segala norma yang berlaku di organisasi. Hasil analisis jawaban responden menunjukkan bahwa rata-rata pegawai di lingkungan Universitas Negeri Gorontalo memiliki tingkat kedisiplinan yang baik, ditinjau dari segi kepatuhannya atas waktu yang meliputi waktu datang dan pulang kantor serta tingkat absensi saat mengikuti apel harian, dari segi kepatuhannya atas norma yang berlaku di kantor yang mencakup absensi saat jam kerja berlangsung, dan dari segi perilaku saat bekerja yang meliputi kesungguhan dalam melaksanakan pekerjaan dan kesesuaian dalam melaksanakan pekerjaan secara prosedural.

Adanya sikap disiplin yang dimiliki para pegawai berdampak positif pada peningkatan kinerja mereka pula. Mempertegas pendapat tersebut hasil pengujian hipotesis statistik juga menemukan bahwa kinerja pegawai di lingkungan Universitas Negeri Gorontalo dipengaruhi secara signifikan oleh disiplin kerja yang dimiliki. Dilihat dari profil responden di mana para pegawai pada umumnya berusia di atas 40 tahun, usia ini masih tergolong produktif mengingat usia produktif kerja 
di Indonesia dipatok dari usia 25 tahun hingga 60 tahun. Pegawai pada usia produktif menurut penelitian yang dilakukan oleh Fuad dan Huda (2018) cenderung memiliki tingkat kedisiplinan, hal disebabkan pada

kondisi usia produktif muncul dorongan dari dalam diri untuk mewujudkan segala bentuk pencapaian berada pada posisi tertinggi.

Berdasarkan hasil penelitian yang dilakukan maka untuk meningkatkan kinerja pegawai di lingkungan Universitas Negeri Gorontalo diperlukan upaya preventif yang dimaksudkan untuk mengarahkan perilaku para pegawai agar tidak bertindak indisipliner. Pemanfaatan sistem presensi berbasis tekonologi saja tidak menjamin pegawai akan bersikap disiplin. Diperlukan kontrol berkala pada setiap unit kerja melalui pimpinan unit guna memastikan para pegawai tetap berada pada koridor kedisiplinan.

Motivasi kerja dan kinerja pegawai

Setiap karyawan memiliki dorongan dalam bekerja yang berbeda-beda. Perbedaan motivasi ini disebabkan adanya keragaman kebutuhan sehinggan proses pemenuhannya pun berbeda antara pegawai satu dengan lainnya. Dalam konteks kinerja Mclelland menyebutkan kurang lebih ada tiga faktor yang mendorong kinerja seseorang dalam organisasi yakni adanya kebutuhan akan pencapaian prestasi, kebutuhan akan kekuasan, dan kebutuhan untuk berafiliasi dengan orang lain. Tidak semua pegawai memiliki ketiga kebutuhan tersebut setidaknya ada satu indikator yang menjadi pemantik semangat kerja pegawai.

Hasil analisis responden menunjukkan bahwa tingkat motivasi pegawai di lingkungan Universitas Negeri Gorontalo tergolong baik. Ditinjau dari ketiga aspek yang dikemukakan oleh Mclelland rata-rata responden mengatakan kebutuhan mereka atas ketiga hal tersebut terpenuhi secara baik selama mereka bekerja di Universitas Negeri Gorontalo. Ini sebuah pertanda baik bagi instansi mengingat motivasi kerja sangat berpengaruh pada peningkatan kinerja pegawai. Bahkan hasil pengujian hipotesis statistik menemukan bahwa motivasi yang dimiliki pegawai di lingkungan Universitas Negeri Gorontalo sangat berpengaruh signifikan pada kinerja mereka.

Merujuk pada hal itu, maka dapat dikatakan bahwa program-program yang dilaksanakan oleh pihak universitas dalam upaya menstimulus motivasi kerja pegawai telah dilaksanakan secara baik dan tepat sasaran. Pencapaian yang dilakukan oleh setiap pegawai selalu ditanggapi secara responsif oleh pihak universitas melalui pemberian remunerasi yang berbasis kinerja. Kesempatan dalam meraih jenjang karir yang tersedia dan dapat diakses oleh semua golongan pegawai yang berkompetensi tentunya ditambah dengan lingkungan kerja yang nyaman sehingga dapat menciptakan suasan kerja yang kondusif.

Loyalitas dan Kinerja Pegawai

Memperoleh loyalitas dari seorang bawahan bukanlah hal yang mudah dan membutuhkan waktu lama untuk menumbuhkannya. Dalam konteks organisasi, loyalitas sering dihubungkan dengan persoalan kesetiaan dan tanggung jawab. Anggota yang loyal dengan organisasinya akan senantiasa menjaga nama baik organisasinya sebagai bentuk kesetiaannya. Secara umum seseorang dianggap loyal 
apabila mau bekerja tanpa mengharapkan imbalan. Namun fakta menunjukkan, loyalitas selalu diukur dari berbagai aspek seperti ketaatan, tanggung jawab, kemauan untuk bekerja sama, rasa memiliki organisasi, hubungan antar pribadi, dan kesukaannya terhadap pekerjaan. Semua aspek tersebut berhulu pada motivasi, di mana dorongan untuk loyal terhadap suatu organisasi juga dipengaruhi oleh indikator-indikator motivasi.

Loyalitas pegawai terhadap instansi juga dilihat tingkat labor turn over yang terjadi, semakin tinggi angka turn over maka dapat dipastikan tingkat loyalitas pegawai juga cenderung rendah. Apabila melihat profil pegawai di lingkungan Universitas Negeri Gorontalo, ditunjukkan jumlah responden yang merupakan pegawai dengan masa kerja di atas 15 tahun ada sebanyak 35 orang. 32 orang adalah pegawai yang bekerja selama kisaran 11 sampai 15 tahun. Namun ada pula pegawai dengan usia di atas 40 tahun yang barumemiliki masa bakti di bawah 10 tahun, yang rata-rata adalah pegawai yang telah lama mengabdi sebelumnya tetapi berstatus sebagai tenaga kontrak dan diangkat menjadi pegawai negeri sipil melalui jalur K2 (kategori 2) sehingga masa bakti terhitung sejak tanggal yang bersangkutan menerima surat tanda pengangkatan pegawai negeri sipil. Mereka para pegawai yang telah mengabdi selama 10 tahun ke atas tentunya tidak diragukan loyalitasnya. Ini dibuktikan dengan lamanya masa kerja yang ditempuh para pegawai. Ini menjadi alasan kenapa para pegawai dikatakan sebagai pegawai yang memiliki tingkat loyalitas yang kuat. Tingginya loyalitas pegawai di lingkungan Universitas Negeri Gorontalo juga dapat dibuktikan dengan prestasi-prestasi yang sudah dicapai oleh kampus itu sendiri, seperti pencapaian dalam meraih akreditas A yang tentunya hal tersebut tidak akan dapat diraih jika tidak didukung oleh loyalitas para pegawai mengingat persiapan-persiapan dalam rangka menghadapi akreditasi membutuhkan kerja keras, semangat dan energi yang cukup besar.

\section{Disiplin, Motivasi, dan Loyalitas dengan Kinerja Pegawai}

Sebelumnya telah dijelaskan bahwa kinerja pegawai di lingkungan Universitas Negeri Gorontalo masing-masing dipengaruhi oleh disiplin kerja, motivasi kerja, serta loyalitas yang dimiliki pegawai. Secara simultan, hasil penelitian juga menemukan bahwa ketiga variabel tersebut berpengaruh terhadap kinerja pegawai. Hasil ini mengindikasikan bahwa untuk memantik kinerja pegawai dibutuhkan lebih dari sekedar penerapan kedisiplinan yang baik, atau pemberian motivasi, ataupun berharap pada loyalitas pegawai. Melainkan harus ada sinergitas antara disiplin, motivasi, dan loyalitas. Penerapan kebijakan yang bersifat preventif guna mengarahkan perilaku disiplin pegawai juga harus didukung penuh oleh tersedianya program-program yang bersifat memotivasi kerja pegawai seperti akses untuk memperoleh kejelasan jenjang karir, pemberian reward berbasis kinerja dan kompetensi pegawai, serta upaya-upaya lainnya yang bersifat kompensasi baik secara finansial maupun non-finansial. Hal ini juga demi menciptakan loyalitas dalam diri pegawai. 


\section{PENUTUP}

Merujuk pada hasil penelitian yang telah dibahas sebelumnya, maka kesimpulan yang dapat ditarik oleh peneliti adalah sebagai berikut;

1. Terdapat pengaruh yang signifikan oleh disiplin kerja terhadap kinerja pegawai di lingkungan Universitas Negeri Gorontalo. Semakin baik penerapan disiplin kerja pada pegawai, akan meningkatkan pula kinerja pegawai.

2. Terdapat pengaruh yang signifikan oleh motivasi kerja terhadap kinerja pegawai di lingkungan Universitas Negeri Gorontalo. Tingginya tingkat motivasi yang dimiliki para pegawai menjadi salah satu kunci dalam meningkatknya kinerja pegawai. Maka keberadaan program-program yang bersifat memotivasi kerja, harus lebih ditingkatkan lagi secara intens.

3. Terdapat pengaruh yang signifikan oleh loyalitas terhadap kinerja pegawai di lingkungan Universitas Negeri Gorontalo. Loyalitas pegawai menjadi alasan kenapa tingkat labor turn over begitu rendah. Ini juga dipicu oleh komitmen universitas dalam membuka kesempatan para pegawainya termasuk di dalamnya para pegawai honorer dalam meraih jenjang karir yang baik.

4. Terdapat pengaruh yang signifikan oleh disiplin kerja, motivasi, dan loyalitas secara simultan terhadap kinerja pegawai di lingkungan Universitas Negeri Gorontalo. Ini mengindikasikan bahwa disiplin kerja saja tidak cukup dalam menstimulus kinerja pegawai. Penerapan kebijakan-kebijakan yang bersifat preventif guna mengarahkan perilaku pegawai agar bersikap disiplin juga harus didukung oleh keberadaan program-program yang dapat memotivasi kerja pegawai. Dengan begitu loyalitas pegawai juga dapat diciptakan dan ditingkatkan. Sinergitas antara ketiga variabel tersebut akan berdampak positif pada peningkatkan kinerja pegawai sehingga akan berdampak pula pada kinerja universitas secara keseluruhan sebagai outcome dari kinerja pegawai. Kesemua faktor ini sangat diperlukan mengingat visi universitas sebagai leading university di kawasan Asia tenggara yang tentunya membutuhkan dukungan dan komitmen yang kuat serta kinerja yang baik dari seluruh elemen yang ada di Universitas Negeri Gorontalo.

\section{DAFTAR PUSTAKA}

A.A. Anwar Prabu Mangkunegara. 2013. Sumber Daya Manusia perusahaan. Remaja Rosdakarya: Bandung

A.A. Anwar Prabu Mangkunegara, 2016, Manajemen Sumber Daya Manusia, Cetakan Ke Enam Belas PT. Remaja Rosdakarya, Bandung.

A.A.Anwar Prabu Mangkunegara. 2017. Manajemen Sumber Daya Manusia Perusahaan. PT.Remaja Rosda Karya, Bandung.

Airasian, PW dan M Russel. 2008 Classroom assessment : Concept and Applications. McGraw-Hill Higher education. Boston College.

Alex S. Nitisemito, 2002, Manajemen Personalia, Ghalia Indonesia, Jakarta.

Ancok, Djamaludin. Validitas dan reliabilitas Instrumen Penelitian dalam

Effendi,Sofian., dan Singarimbun, Masri. 1995. Metode Penelitian Survai. EdisiRevisi. Jakarta : LP3 ES. 
Anoraga, Panji, 2014. Psikologi Kerja, Rineka Cipta, Jakarta.

Arikunto, S. (2006). "Prosedur Penelitian Suatu PendekatanPraktik". Jakarta : PT RINEKA CIPTA.

Asri Warnanti dan Firstly Dito Pranata (2014). Motivasi dan disiplin kerja pengaruhnya terhadap kinerja pegawai pada bidang pendaftaran dan informasi penduduk di dinas kependudukan dan catatan sipil kota bekasi jawa barat. SEMINAR NASIONAL DAN CALL FOR PAPERS UNIBA 2014.

Good Governance Menuju Kesejahteraan dan Kemandirian

B. Siswanto Sastrohadiwiryo. 2002. Manajemen Tenaga Kerja Indonesia Pendekatan Administrasi dan Operasional. Jakarta : Bumi Aksara

Bernardin, H. John, danJoyce E.A Russel. (2003). Human resource management (An Experimental Approach International Edition). Mc. Graw-Hill Inc.Singapore.

Budiyanto, M.T, Eko, 2013, Sistem Informasi Manajemen Sumber Daya Manusia, Yogyakarta, Graha Ilmu.

Danang, Sunyoto. 2016. Manajemen Sumber Daya Manusia. Jakarta: PT Buku Seru. http://repository.upi.edu/17628/4/S_MBS_1001311_Bibliography

Dwiyanto, Agus. 2006. "Transparansi Pelayanan Publik", dalam Agus Dwiyanto,ed .2006. Mewujudkan Good Governance Melalui Pelayanan Publik. Yogyakarta: Gadjah Mada University Press.

Edy Sutrisno. 2016. Manajemen Sumber Daya Manusia. Jakarta : Prenadamedia Group.

Evawati Khumaedi (2016) Pengaruh Disiplin dan Motivasi Kerja terhadap Kinerja Pegawai pada Dinas Sentra Operasi Terminal PT.Angkasa Pura II. Jurnal Ilmiah Manajemen dan Bisnis Volume 2, Nomor 1, Maret 2016

Hasibuan, Malayu S.P. 2017, Manajemen Sumber Daya Manusia. Edisi Revisi, PT.Bumi Aksara Jakarta.

Indriantoro N dan Supomo B. 2002. Metodologi Penelitian Bisnis, Cetakan Kedua, Yogyakara; Penerbit BFEE UGM.

Istiningsih. (2006). Pengaruh Kepemimpinan terhadap Motivasi dan Kinerja Karyawan STMIK Amikom Yogyakarta, Jurnal Ilmiah Manajerial, VOL. 2. NO. 1. MARET 2006.

Joyce Sagita Novyanti, 2015. Pengaruh Motivasi Kerja, Lingkungan Kerja dan Disiplin Kerja terhadap Kinerja Pegawai pada Bappeda Provinsi Sulawesi Tengah. e-Jurnal Katalogis, Volume 3 Nomor 1, Januari 2015 hlm 105-115 ISSN: 2302-2019

Kusumo, B.C.S. (2006). Hubungan antara Persepsi terhadap Iklim Organisasi dan Kepuasan Imbalan Kerja denga Loyalitas Kerja pada Karyawan . Surakarta: Fakultas Psikologi Universitas Muhammadiyah Surakarta.

Moeheriono. 2012. "Pengukuran Kinerja Berbasis Kompetensi”. Jakarta: Raja Grafindo Persada.

Nindyati, Ayu D. 2014. Sex Role Identity dan Self-Efficacy sebagai Mediator Hubungan Tiga Kebutuhan menurut McClelland dengan Kinerja Beauty Advisor PT. X di Jakarta. Retrieved January 10, 2015 from http://www.academia.edu 
Poerwopoespito, F.Z. 2004.Mengatasi Krisis Manusia di Perusahaan. PT Gramedia Widiasarana Indonesia.Jakarta.

Poerwopoespito, 2005, Mengatasi Krisis Manusia di Perusahaan, Gramedia Widiasarana Indonesia, Jakarta.

Robbins, S dan Coulter, M. 2012. Manajemen, Edisi Kesebelas, Penerbit PT Indeks: Jakarta.

Sarworini, Fithriani. 2007. "Hubungan Kemampuan dan Motivasi terhadap Kinerja Pegawai Dinas Kependudukan, Tenaga Kerja dan Transmigrasi Kabupaten Karanganyar". Semarang:

UNDIP.Diperoleh dari eprints.undip.ac.id/7655/1/D2A003017_Fithriani_Sarworini.pdf.

Singodimedjo, 2016. Dimensi dan Indikator Disiplin Kerja. Surabaya. SMMAS

[29] Simamora, Henry. 2015. Manajemen Sumber Daya Manusia. Yogyakarta: STIE YKPN.

Sinungan Muchdarsyah. 2014. Produktivitas Apa Dan Bagaimana. Jakarta: Bumi Aksara.

Siagian, Sondang P,2012.. Kiat Meningkatkan Produktivitas Kerja. Jakarta: PT Rineka Cipta.

Siagian, Sondang P. 2016. Manajemen Sumber Daya Manusia. Jakarta: Bumi Aksara

Yapanto, L. M., Tanipu, F., Paramata, A. R., \& Actors, E. (2020). THE EFFECTIVENESS OF FISHERY COOPERATIVE INSTITUTIONS. 17(25), 1329-1338.

Siswanto. (2010). Pengantar Manajemen. -Cet.6. Jakarta: Bumi Aksara.

Slamet, Achmad. 2007. Manajemen Sumber Daya Manusia. Universitas Negeri Semarang Press. Semarang

Sujarweni, Wiratna. 2014. Metodologi penelitian: Lengkap, praktis, dan mudah dipahami. Yogyakarta: PT Pustaka Baru

Suprayitno, E. dan Priambodo, R. E. A(2007). Penerapan Good Corporate Governance Sebagai Landasan Kinerja Perbankan Nasional",Usahawan, No. 05.

Sundram, S., Venkateswaran, P. S., Jain, V., Yu, Y., Yapanto, L. M., Raisal, I., Gupta, A., \& Regin, R. (2020). The Impact of Knowledge Management on The Performance of Employees: The Case of Small Medium Enterprises. Productivity Management, 25(1S), 554-567.

Valensia angelina wisti dapu (2018).the influence of work discipline, leadership, and motivation on employee performance at pt. trakindo utama manado. Jurnal EMBA Vol.3 No.3 Sept. 2015, Hal.352-361

Zainun Bukhori, 2014, Manajemen dan Motivasi, BumiAksara, Jakarta. 